J-ABDIPAMAS (Jurnal Pengabdian Kepada Masyarakat)

Vol. $4 \bullet$ No. $2 \bullet 2020$

ISSN : 2581-1320 (Print) ISSN : 2581-2572 (Online)

Homepage: http://ejurnal.ikippgribojonegoro.ac.id/index.php/J-ABDIPAMAS

\title{
SOSIALISASI DAN EDUKASI PEMBUATAN NUGGET KAYA ANTIOKSIDAN DARI GAMBAS (Luffa Acutangula) DI PEKANBARU
}

\author{
Putri Ade Rahma Yulis ${ }^{1}$, Arief Yandra Putra ${ }^{2}$, Desti $^{3}$, Aisyah Meisya Putri $^{4}$ \\ ${ }^{1}$ Universitas Islam Riau. Email: putriaderahmayulis@edu.uir.ac.id \\ 2Universitas Islam Riau. Email: ariefyandra0811@edu.uir.ac.id \\ 3Universitas Islam Riau. Email: destibio@edu.uir.ac.id \\ ${ }^{4}$ Universitas Islam Riau. Email: aisyah@student.ac.uir.id
}

\begin{abstract}
Long-term consumption of nuggets can lead to: increasing heart attacks, increasing body weight, triggering diabetes and triggering high blood pressure. That is because in processed food manufacturers usually add preservatives, excessive MSG and imbalanced nutrition. Because there are still many people, especially mothers in partner neighborhoods in Perhentian Marpoyan, who often complain that their children do not like to consume vegetables, and many make processed nuggets as manufacturers for their children, in this service we provide a presentation on how to process Nugget. Gambas are rich in antioxidants, so they are very good for consumption especially for the growth process of children. The existence of this community service was very welcomed by the local residents, this can be seen from the enthusiasm of residents asking questions related to the problems presented regarding the processing of nuggets as well as from the impression of some residents who want this kind of activity to be carried out continuously so that more people feel the benefits and they will try to apply the knowledge from the education that has been carried out.
\end{abstract}

Keywords: fast food, nuggets, gambas, antioxidants

\begin{abstract}
ABSTRAK
Konsumsi nugget dalam jangka panjang dapat menyebabkan: meningkatkan serangan jantung, meningkatkan berat badan, memicu diabetes dan memicu tekanan darah tinggi. Hal itu dikarenakan didalam makanan olahan pabrikan biasanya ditambahkan pengawet, MSG yang berlebihan dan nutrisi yang tidak seimbang. Dikarenakan masih banyaknya masyarakat terutama Ibu-Ibu di lingkungan mitra di kelurahan Perhentian Marpoyan yang sering mengeluhkan anak-anaknya tidak suka mengkonsumsi sayuran, serta banyak yang menjadikan nugget olahan pabrikan sebagai bekal anak-anak mereka, pada pengabdian ini kami memberikan pemaparan bagaimana dapat mengolah Nugget Gambas yang kaya Antioksidan, sehingga sangat baik dikonsumsi terutama untuk proses pertumbuhan anak-anak. Adanya kegiatan pengabdian ini sangat disambut baik oleh warga setempat, hal ini dapat dilihat dari antusiasnya warga mengajukan pertanyaan-pertanyaan sehubungan masalah yang dipaparkan mengenai pengolahan nugget serta dari kesan beberapa warga yang ingin kegiatan sejenis ini terus dilakukan secara berkesinambungan sehingga lebih banyak lagi yang merasakan manfaatnya dan mereka akan mencoba mengaplikasikan pengetahuan dari edukasi yang telah dilaksanakan.
\end{abstract}

Kata Kunci: makanan cepat saji, nugget, gambas, antioksidan 


\section{PENDAHULUAN}

Dewasa ini dikarenakan perubahan gaya hidup yang lebih modern, sehingga semuanya menjadi serba praktis dan kemajuan teknologi yang pesat seringkali membuat kita mengkonsumsi makanan yang proses penyajiannya lebih praktis. Salah satu penyebabnya adalah padatnya jadwal kesibukan masing-masing individu sehingga pilihan makanan yang akan dikonsumsi adalah yang cepat saji, jadi lebih praktis dan tidak membuang waktu. Sekarang ini tidak sedikit makanan yang berbahaya bagi tubuh beredar di masyarakat. Karena ketidaktahuan masyarakat tentang makanan berbahaya merupakan salah satu faktor menyebarnya makanan-makanan berbahaya.

Berdasarkan hasil identifikasi berupa wawancara dengan beberapa warga di lingkungan mitra di kelurahan Perhentian Marpoyan - Pekanbaru diketahui bahwa Ibuibu di wilayah tersebut banyak mengeluhkan anak-anak mereka yang tidak menyukai sayuran, selain itu perihal persoalan lainnya dikarenakan banyaknya ibu-ibu bekerja yang mempunyai waktu cukup sedikit memilih menyediakan sarapan ataupun bekal sekolah anak-anak mereka dengan makanan olahan atau pabrikan salah satunya seperti nugget. Sementara kita ketahui bahwa usia anak-anak sangat membutuhkan kecukupan gizi yang seimbang, kurangnya konsumsi sayuran memberikan dampak buruk terhadap anak-anak salah satunya bagi proses pencernaan, kemudian konsumsi makanan olahan pabrikan seperti nugget dalam jumlah yang cukup banyak juga tidak baik dikarenakan kita tidak dapat memastikan kandungan gizi didalamnya serta kehigienisan proses pembuatannya, selain itu makanan olahan seperti itu sebagian besar mengandung bahan tambahan makanan penyedap yang jika dikonsumsi dalam jangka waktu panjang menjadi penyebab beberapa jenis penyakit. Adanya permasalahan-permasalahan inilah yang menjadi dasar pelaksanaan pengabdian di daerah lingkungan mitra.

Makanan seperti nugget salah satunya seringkali dipilih masyarakat untuk dikonsumsi. Komposisi utama nugget adalah daging, biasanya dari ayam, ikan atau kombinasi dengan protein nabati (Basri \& Aziz, 2009). Nugget merupakan salah satu bentuk produk makanan beku siap saji, yaitu produk yang telah mengalami pemanasan sampai setengah matang (precooked), kemudian dibekukan. Padahal kandungan yang ada didalam makanan tersebut tidak sepenuhnya baik untuk dikonsumsi, terlebih lagi nugget banyak disajikan oleh ibu-ibu sebagai bekal sekolah karena sangat disukai oleh masyarakat terutama anak-anak, banyak dipasaran produk nugget yang mempunyai merek-merek yang berbeda (Evanuarini \& Purnomo, 2011) dan penyajiannya praktis.

Kita memerlukan kebutuhan gizi yang mencukupi terutama bagi yang memiliki jadwal kesibukan yang padat untuk dapat menunjang kesehatan dalam menjalankan berbagai aktivitas. Oleh karena itu diharapkan asupan yang masuk ke tubuh memenuhi aspek karbohidrat, protein, lemak, serat , mineral dan vitamin nya. Ini kita dapatkan dari berbagai makanan yang kita konsumsi seperti daging, telur, nasi, dan sayur-sayuran.

Konsumsi nugget siap saji yang diolah dipabrikan tidak dapat memberikan jaminan mengandung komposisi yang cukup untuk kebutuhan gizi, terutama anak-anak, serta mekanisme pengolahan nya pun tidak dapat kita jamin tingkat higienisnya. Konsumsi nugget yang termasuk makanan cepat saji jika dikonsumsi dalam jangka panjang dapat menyebabkan : meningkatkan serangan jantung, membuat ketagihan, 
meningkatkan berat badan, memicu diabetes dan memicu tekanan darah tinggi. Hal itu dikarenakan didalam makanan olahan pabrikan biasanya ditambahkan pengawet, MSG yang berlebihan dan nutrisi yang tidak seimbang. Selain itu nugget yang diolah dipabrikan rata-rata berbahan dasar daging, namun tidak dapat kita pastikan mengandung $100 \%$ daging namun dapat bercampur dengan bagian-bagian lainnya , sementara kita ketahui bahwa kita harus mendapatkan asupan makanan yang seimbang dengan didukung adanya serat, vitamin dan mineral dari sayuran. Namun, tidak semua orang menyukai sayuran, dikarenakan menurut sebagian orang rasa yang dimiliki sayuran kurang enak bahkan baunya pun dapat menjadi masalah.

Dikarenakan masih banyaknya masyarakat terutama Ibu-Ibu di lingkungan mitra yang sering mengeluhkan anak-anaknya tidak suka mengkonsumsi sayuran, serta banyaknya Ibu-ibu bekerja yang sering sekali menjadikan nugget olahan pabrikan sebagai bekal anak-anak mereka, pada pengabdian ini kami ingin memberikan pemaparan bagaimana dapat mengolah Nugget Gambas yang kaya Antioksidan, sehingga sangat baik dikonsumsi terutama untuk proses pertumbuhan anak-anak. Bahan dasar pembuatan Nugget Gambas tetaplah ayam, tetapi memiliki keunggulan dimana Nugget Gambas ini tidak menggunakan bahan pengawet sehingga bisa dipastikan Nugget Gambas ini sangat baik untuk kesehatan tubuh dan memiliki rasa yang enak. Nugget Gambas memberikan alternatif dalam membantu memenuhi kebutuhan tubuh yang sangat besar yang mungkin masih belum terpenuhi melalui makanan yang dikonsumsi. Didukung oleh komposisi sayuran gambas berdasarkan USDA National Nutrient Data Base mengandung protein, karbohidrat, serat, vitamin A, B dan C, mineral bahkan lemak. Selain itu Gambas dapat ditanam di berbagai tempat dan musim tergantung varietasnya (Maulidah \& Ashari, 2017)

Adanya persoalan yang telah dipaparkan diatas, sehingga tim pengabdian dari prodi Pendidikan Kimia UIR merasa perlunya mengadakan edukasi terkait hal ini, yaitu Edukasi Pengolahan Nugget Kaya Antioksidan dari Gambas di Kelurahan Perhentiyan Marpoyan, Pekanbaru. Adanya Nugget yang dipadukan dengan sayuran bertujuan untuk dapat memenuhi kebutuhan konsumen akan gizi makanan yang tidak sempat mengkonsumsi sayuran segar secara langsung (Rujiah, Retty Ninsix, 2013). Tujuan umum yang ingin dicapai melalui kegiatan penyuluhan mengenai pengolahan nugget dari gambas ini adalah mitra dapat mengetahui efek konsumsi produk olahan pabrikan. Kemudian mitra dapat memanfaatkan sayur gambas untuk dijadikan bahan nugget, dimana sayur gambas ini memiliki kandungan nutrisi yang cukup banyak untuk tubuh. Jadi warga terutama ibu-ibu dapat menyajikan nugget buatan sendiri yang jauh lebih higienis dalam proses pengolahannya dan juga komposisi nya yang diimbangi karena mencampurkan sayuran didalamnya. Dengan demikian dapat memberikan pemahaman secara umum tentang produk pengolahan pangan.

\section{METODE PELAKSANAAN}

Kegiatan pengabdian ini dilaksanakan di RT 003 RW 001 Kelurahan Perhentian Marpoyan, Kecamatan Marpoyan Damai Kota Pekanbaru-Riau. Kegiatan pengabdian dilaksanakan pada bulan Januari 2020. 


\section{Proses Pelaksanaan}

Transfer IPTEKS yang dilakukan oleh Tim Pelaksana kegiatan Pengabdian kepada Masyarakat (PkM) Prodi Pendidikan Kimia dilakukan pada tiap tahapan dengan menggunakan prinsip bahwa setiap informasi dan inovasi yang diterima oleh Mitra sebaiknya melalui proses, mendengar, mengetahui, mencoba, menerima, meyakini, dan melaksanakan serta mengevaluasi. Agar setiap proses berlangsung dengan baik, maka penyampaian inovasi kepada Mitra dilakukan dengan tahapan penjelasan, diskusi, praktek serta dilakukan pembimbingan.

Penerapan IPTEKS yang dilakukan adalah dengan melakukan pemaparan kepada warga peserta pengabdian tentang pentingnya memilih produk makanan yang sehat, dan bergizi untuk tubuh serta dampak ketergantungan produk makanan cepat saji. Kemudian diberikan edukasi bahwa gambas dapat dijadikan bahan tambahan untuk pembuatan nugget, dimana gambas ini kaya akan nutrisi sehingga akan sangat baik untuk menganti kebutuhan sayuran oleh tubuh terutama untuk anak-anak yang sebagian besar tidak suka mengkonsumsi sayuran. Pamaparan secara langsung melalui presentasi Power Point (PPT). Kemudian dilakukan praktek mengenai pemanfaatan sayur gambas tersebut oleh beberapa warga dan dirasakan manfaat dari kegiatan edukasi tersebut.

\section{Kontribusi dan Partisipasi Mitra}

Mitra ikut berpartisipasi aktif dalam kegiatan pengabdian kepada masyarakat yang dilaksanakan. Mitra ikut memberikan sumbangsih berupa tenaga, fikiran dan jasa dalam kegiatan yang dilaksanakan oleh tim pengabdian masyarakat program studi Pendidikan Kimia.

\section{Evaluasi dan Keberlanjutan Program}

Tahap evaluasi disini tim pengabdian melakukan peninjauan dengan cara diskusi untuk mengetahui respon lanjutan yang dilakukan oleh ibu-ibu terkait pemanfaatan sayur gambas tersebut sebagai salah satu bahan olahan nugget. Untuk keberlanjutan program ini diharapkan agar warga yang sebelumnya terutama ibu-ibu yang lebih sering membeli produk olahan nugget di luar, dapat mulai mengaplikasikan ilmunya untuk mengolah nugget sendiri dirumah, sehingga dapat lebih terjamin proses pembuatannya serta dapat mengontrol bahan-bahan tambahan yang baik untuk dikonsumsi. Selain itu dapat memanfaatkan gambas di dalam nugget tersebut sehingga nugget produk rumahan yang dihasilkan tidak hanya praktis, tapi lebih terjamin dan bergizi

\section{HASIL DAN PEMBAHASAN}

\section{Kegiatan Sosialiasi dan Edukasi Pengolahan Nugget dari Gambas}

Pelaksanaan kegiatan dilakukan pada bulan Januari 2020 di daerah Kelurahan Perhentian Marpoyan, Kecamatan Marpoyan Pekanbaru. Kegiatan ini dihadiri 40 peserta, kemudian ditambah 3 orang Tim Dosen Universitas Islam Riau dan 2 orang mahasiswa Pendidikan Kimia , jumlah yang tidak terlalu banyak ini disebabkan beberapa peserta berhalangan hadir dalam mengikuti kegiatan sosialisasi ini dikarenakan beberapa hal yang mendesak setelah dikonfirmasi oleh ketua mitra dalam pelaksanaan pengabdian ini, 
seharusnya peserta yang akan mengikuti sekitar 60 orang. Adapun tahapan pelaksanaan kegiatan setelah dibuka oleh mitra kemudian dilanjutkan oleh tim pengabdian untuk memberikan edukasi seputar tujuan diadakannya pengabdian dengan tema terpilih kemudian pemaparan mengenai bahaya konsumsi jangka panjang makanan olahan pabrikan yang dapat memicu berbagai jenis penyakit, selanjutnya pemaparan menegnai kandungan gizi pada sayur Gambas seperti berbagai jenis vitamin, mineral serta kaya akan antioksidan, manfaat yang dapat diperoleh dari sayur Gambas , proses pengolahan nugget dengan memanfaatkan sayur gambas.

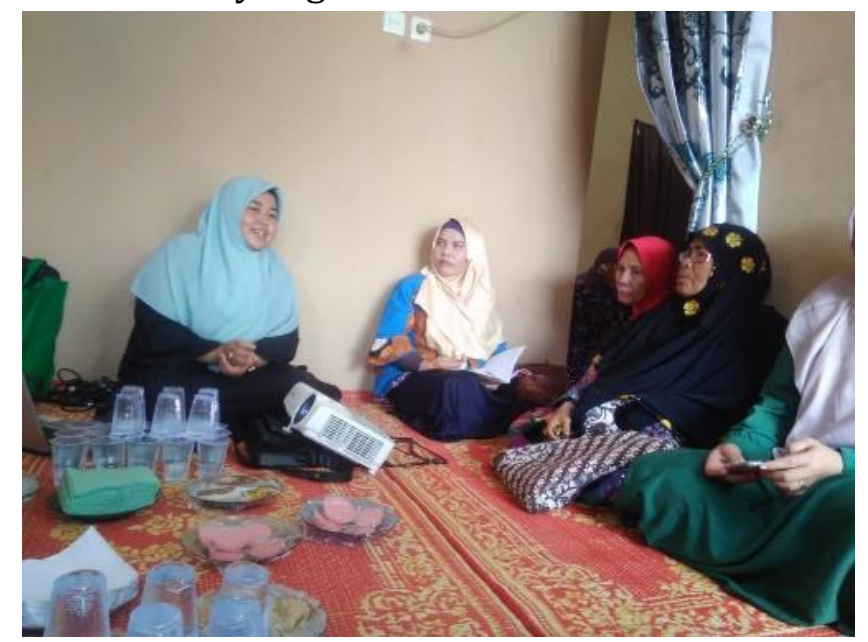

Gambar 1. Proses Pemaparan Materi oleh Tim Pengabdian

Setelah diberikan Edukasi mengenai makanan olahan pabrikan serta manfaat besar dari olahan sayur Gambas kemudian dilanjutkan sosialiasi terkait hasil penelitianpenelitian terkait dengan kemampuan ekstrak dari sayur gambas ini yang telah dipublikasikan pada artikel-artikel nasional. Setelah pemaparan tim pengabdian kemudian dilanjutkan dengan diskusi terkait pemanfaatan sayur Gambas. Diskusi yang terjadi berjalan cukup efektif hal ini dilihat dari sangat antusiasnya peserta pengabdian di lingkungan mitra menanyakan informasi lebih lanjut tentang kandungan gizi dan bahaya makanan olahan, kemudian mereka juga sangat tertarik dengan mengetahui sayur gambas yang sering mereka konsumsi mempunyai manfaat yang cukup besar , kandungan gizi yang cukup lengkap. Sehingga adanya pemaparan pengabdian ini menjadi masukan untuk Ibu-ibu tersebut lebih memperhatikan asupan yang seharusnya diberikan ke anakanak mereka. Ibu -ibu tersebut pun menjanjikan akan memulai untuk membiasakan mengolah makanan sendiri, sehingga dapat memastikan kandungan gizi serta kehigienisan proses pembuatan nya jadi dapat memastikan kesehatan keluarga dapat lebih terjamin baik dalam jangka waktu pendek maupun jangka waktu yang lebih panjang.

\section{Hasil Kegiatan}

Hasil kegiatan pengabdian kepada masyarakat ini disambut baik oleh anggota masyarakat di daerah Kartama Perhentian Marpoyan, Kecamatan Marpoyan Damai. Beberapa hal yang dapat didapatkan dari kegiatan ini diantaranya : 
a. Meningkatnya pengetahuan ibu-ibu anggota PKK RT 003 RW 001 Kelurahan Perhentian Marpoyan, Kecamatan Marpoyan Damai Kota Pekanbaru-Riau. Mengenai bahaya dari konsumsi makanan olahan pabrikan dalam jangka panjang

b. Meningkatkan kewaspadaan ibu-ibu anggota PKK untuk memilih dan memilah asupan terbaik untuk anak-anak mereka ke depannya

c. Menambah pemahaman ibu-ibu anggota PKK Kecamatan Marpoyan Damai untuk dapat memanfaatkan sayur Gambas sebagai bahan olahan nugget karena kandungan gizinya yang cukup lengkap serta antioksidan nya yang cukup tinggi sehingga sangat baik untuk dikonsumsi anak-anak

d. Meningkatnya kesadaran masyarakat setempat mengenai kemungkinan pola hidup sehat dimulai dari makanan-makanan pilihan terbaik yang pasti kandungan gizinya seimbang, proses pengolahan yang pasti lebih higienis.

Pengukuran kemampuan pengetahuan Ibu-Ibu PKK ini tidak dilakukan secara kuantitatif dengan menggunakan instrument khusus melainkan hanya secara kualitatif dari proses diksusi dan Tanya jawab yang berlangsung setelah pemaparan materi. Kemudian juga dinilai dari angket kepuasan mitra yang disebarkan dimana dari beberapa item penilaian dapat dilihat bahwa Ibu-Ibu PKK sebagai mitra merasakan bahwa kegiatan ini sangat bermanfaat dan mengharapkan dapat terus dilajutkan ke depannya.

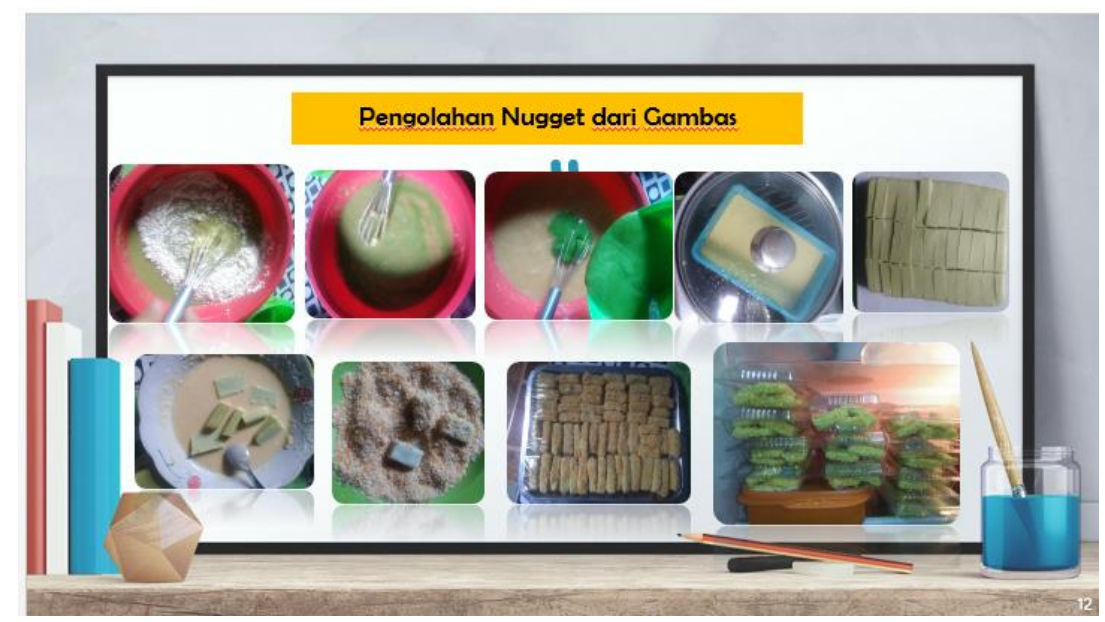

Gambar 2. Pengolahan Nugget dari sayur Gambas (Luffa Acutangula)

\section{SIMPULAN}

Kegiatan pengabdian masyarakat ini disambut baik karena memberikan dampak yang positif, dimana dengan adanya forum diskusi mendorong munculnya kesadaran masyarakat mengenai bahayanya konsumsi makanan olahan pabrikan secara terus menerus dalam jangka waktu panjang terutama untuk anak-anak. Sehingga dari kegiatan ini Ibu-ibu PKK tersebut dapat mengolah sendiri asupan makanan untuk anak-anak mereka dari bahan yang mempunyai kandungan gizi yang lebih lengkap, menghindari pemakaian bahan tambahan makanan dalam jumlah banyak serta dapat memastikan proses pengolahan yang jauh lebih higienis sehingga mereka dapat lebih memastikan kesehatan anak-anak mereka nantinya. Jadi mereka secara tidak langsung juga dapat 
memastikan anak-anak mengkonsumsi sayuran tapi dalam bentuk olahan yang mereka sukai.

\section{UCAPAN TERIMA KASIH}

Terima kasih kami ucapkan kepada Lembaga Penelitian dan Pengabdian Universitas Islam Riau (LPPM UIR) yang telah membiayai kegiatan Pengabdian Kepada Masyarakat ini dengan nomor kontrak : 260/PkM/Kontrak/LPPM-UIR/11-2019.

\section{DAFTAR RUJUKAN}

Basri, N. F., \& Aziz, F. A. (2009). Asian Journal of Food and Agro-Industry. Physicochemical and Sensory Properties of Commercial Chicken Nuggets, 2(02), 171-180.

Evanuarini, H., \& Purnomo, H. (2011). Physical and Organoleptic Quality of Chicken Nuggets Fried At Different Temperature and Time. Journal of Agriculture and Food Technology, 1(8), 133-136.

Maulidah, N. I., \& Ashari, S. (2017). The Effect Of Maturity Level And Drying Time To Seed Quality Of Ridged Gourd Hybrid ( LUFFA ACUTANGULA ). Jurnal Produksi Tanaman, 5(3), 417-423.

Rujiah, Retty Ninsix, dan Z. H. (2013). Pengolahan Nugget Sayur. Jurnal Teknologi Pertanian, 2(1), 35-47. 
66 J-Abdipamas, Vol. 4, No. 2 Oktober, 2020 